\title{
DIMENSIONS OF THE FUNDING PROGRAMMES FOR SUSTAINABLE RURAL DEVELOPMENT IN ROMANIA
}

Ioana Sonia Comanescu ${ }^{1}$,Assoc. Prof.; Diana Foris ${ }^{2}$,Assist. Prof and Tiberiu Foris ${ }^{3}$,Prof. ${ }_{1,2}$ Faculty of Food and Tourism, Transilvania University of Brasov, Romania; ${ }^{3}$ Faculty of Economic Sciences and Business Administration, Transilvania University of Brasov, Romania

\begin{abstract}
As part of the Common Agricultural Policy, the European Union offers a complex system of rural development interventions, an increased flexibility, allowing through the Rural Development Plan the design of financial envelope according to the national specificity, based on the principle of subsidiarity, The paper examines, using a comparative analysis based on national data, as well as the statistics provided by Eurostat, how Rural Development Plan and the National Plan for Local Development (funded by the national government) have effectively contributed to the sustainable development of rural areas from Romania, emphasizing some specific aspects of the implementation.
\end{abstract}

Key words: rural development, funding programmes, sustainability, agriculture, environment, competitiveness.

JEL code: O21, O22, Q01, Q18, R51.

\section{Introduction}

The major objectives of the rural development policy are the enhancement of the quality of life of the rural population and improvement of the overall competitiveness of rural areas; whilst agricultural policy has the improvement of farmers' incomes as its main goal, even if agricultural policy objectives have been evolving in many countries and at present they often include environmental objectives and the production of non-output goods (multifunctionality of agriculture)(OECD, 2006).

TheEuropean Union sustainable development strategy emphasizes the need for a cost-effective implementation of political measures, being relevant for funding programs for rural areas (Uthes 2017).

Romania has a rich natural environment and high biodiversity, including the Carpathian Mountains, the Danube Delta Biosphere Reserve and 300,000 ha of virgin forest. Natural and seminatural ecosystems cover around $47 \%$ of the national territory. Approximately 2.4 million ha of the country's semi-natural grassland is classified as of High Nature Value (HNV).

Rural areas are typified by a scattered population and very low quality infrastructure (only $33 \%$ of rural residents are connected to a water supply network, only $10 \%$ to a sewerage system and only $10 \%$ of rural roads are of adequate standard). Basic social infrastructure (health and education systems, finance and credit provision etc) is also much less developed than in urban areas. These factors affect the quality of life in rural areas, hamper economic development, increase outmigration, and exacerbate health and environmental problems (Brandt 2007). The rural economy is highly dependent on agriculture and forestry, with low development of alternative activities, and lower incomes than urban areas. As Member State since the $1^{\text {st }}$ of January 2007, Romania choose to have one RDP for the whole country.

The aim of the paper is to analyse the way the funding through the NPRD contributes to a sustainable rural development, by analyzing the indicators related to the economic, social and environmental dimensions of the rural sustainable development, in the economic, social and environmental indicators, in accordance with the stipulations of the National Plan for Rural Development. 


\section{Achievements of the National Rural Development Plan 2007-2013}

During the 2007-2013 funding period, improving the quality of life was a stated goal of the rural development policy within the framework of the EAFRD Regulation, and a strategic priority of the European Union (EU) (Moser 2018).

The overall objective of the first planned period of the National Plan for Rural Development NPRD was to increase the competitiveness of the agri-food and forestry sectors, by improving rural areas, quality of life in rural areas and environment protection. In order to achieve these objectives, at NRDP were defined four axis: Axis 1 "Improvement competitiveness of the agricultural and forestry sector", the overall financial allocation, was 4.785.667.281 Euro, out of which 2.885.269.470 Euro public expenditure and 1.900.397.811 Euro private expenditure. The main share has been assigned for Measure 121 Modernization of agricultural holdings (31,3\%), targeting the specific objectives: introduction and development of new technologies and procedures, production diversification, adjusting the profile, level and quality of production to market requirements including the organic production, as well as obtaining and using energy from renewable sources (Fig. 1a).
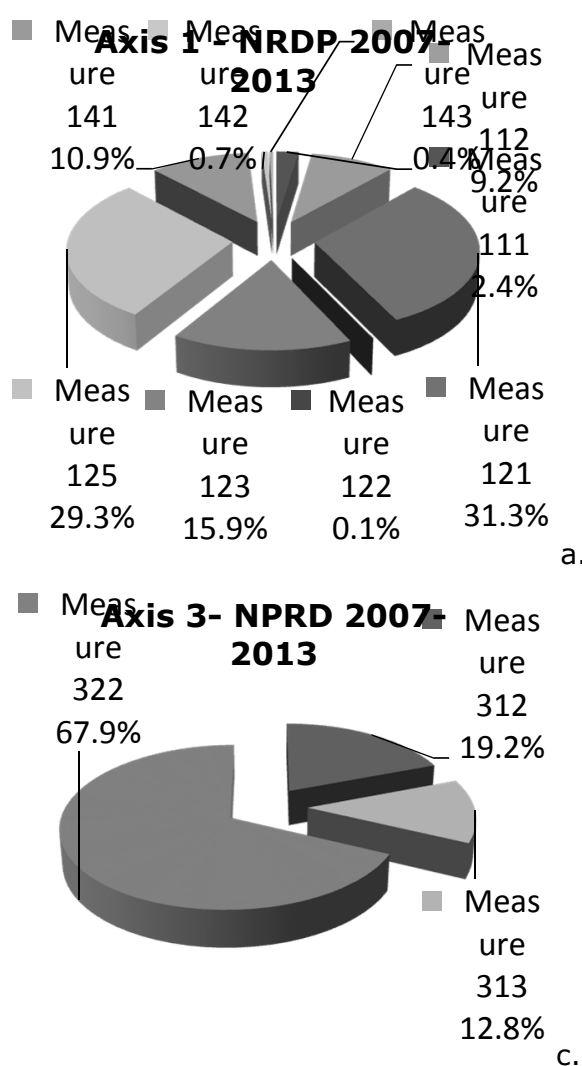
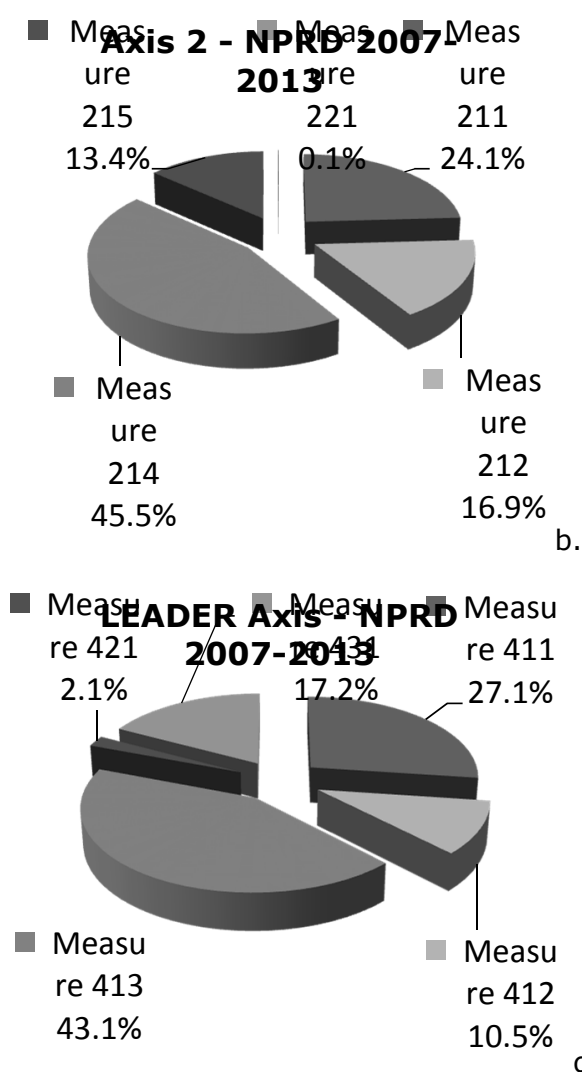

Source: Authors' calculation based on MADR data

Fig. 1. National Plan for Rural Development 2007-2013, share of allocation by measures.

Axis 2 "Improvement of environment and rural area", with a total cost of $€ 3.163 .717$, of which $€$ 3.163.239 public expenditure. A share of $45,5 \%$ has been designed for Measure 214 Agrienvironment payments, needed to support the sustainable development of rural areas. For Measure 211 Support for Disadvantages Mountainous Areas, the total allocated cost was 769,555,055 Euro, representing a share of $24.1 \%$ (Fig. 1b). Axis 2 measures for agricultural land have contributed to: maintaining biodiversity - 6,073 million ha; soil quality - 864 thousand ha; water quality 2,186 million ha; avoiding the isolation and abandonment of land - 6,014 million ha; mitigation of climate change - 1,431 million ha. 
Axis 3 "Rural diversification and quality of life", with an overall cost of $€ 2.719 .923$, of wich $€$ 2.337.695 Euro public expenditure. A large amount of the funding has been allocated for village renewal and rural services. The achievements: Measure 312 „Micro-enterprises": 9,499 applications, 3,130 contracted projects, $€ 402,7$ million euro; payments: $€ 264$ million; Measure 313 "Agro-tourism": 1,684 contracted projects, of $€$ 236,7 million euro; Payments: $€ 86.4$ million; Measure 322 "Village Renovation and Development": 3,317 applications, of $€$ 7,64 billion (allocation of EUR 1,6 billion); 877 contracted projects, of 1.73 billion euros; payments: $€ 1.4$ billion (Fig. 1c).

Axis 4 LEADER, with a total cost of 524.094 Euro, of which 386.164 public expenditure. The main measures at Axis 4 level in terms of total allocated budget are 41 "Implementation of local development strategies "(ie Leader Axis 1 - 411 and Leader Axis 3 - 413) and 431 Local Action Groups, acquiring skills and animating the territory (Fig. 1d).

Analysing the achieved results through the NRDP 2007-2013, 2,597 farms and over 73,000 farmers (through measures 112 - Young farmers, 141 - semi-subsistence farms and 121 - farm modernization) were funded. 3.133 non-agricultural SMEs from rural areas and 1,011 processing units (Measure 123) received funding. Over 3 million inhabitants benefited from village infrastructure (Measure 322): 3,862 km of modernized communal roads, 2,900 km of water supply network and $4,345 \mathrm{~km}$ of built-up sewerage network. There have also been built 1,967 km of agricultural roads and 1,610 km of forest roads (Measure 125). Also, through the NRDP 2007-2013, 137 projects of irrigation works were funded and works for flood protection of 44,794 ha were carried out. A total of 318,794 ha have been carried out for the modernization and rehabilitation of the irrigation infrastructure.The Agency for Rural Investment Finance (AFIR) has paid over 7.4 billion euros to beneficiaries of RDP 2007-2013, reaching . an absorption degree of over $86 \%$ of the total European funds allocated to Romania.

Overall, in the period 2009-2015, the measures analysed through the counterfactual analysis has created a net effect of about 20.760 jobs. The net effect in the non-agricultural sector reaches 7.142 which represents $13 \%$ of the target value of the impact result indicator (AFIR 2019).

\section{Targets of the 2014 - 2020 Rural Development Program for Romania}

The goals of the Europe 2020 Strategy, which Romania has also assumed and to which it has to contribute, according to the National Reform Program, are: •employment rate of the population aged between 20 and 64 years of $75 \%$ (RO $70 \%$ ); $\cdot R$ \& D investment rate of $3 \%$ of European Union GDP (RO $2 \%) ; \cdot 20 / 20 / 20$ target on energy and climate change: greenhouse gas emissions by $20 \%$ below 1990 levels; $\cdot 20 \%$ of the energy produced from renewable sources (RO $24 \%$ ) $; \cdot 20 \%$ increase in energy efficiency; •Early school dropout rate below $10 \%$ (RO $11.3 \%$ ); •the share of young people aged 30-34, who graduates from a form of tertiary school, at least $40 \%$ (RO $26.7 \%$ ); reducing the number of people exposed to poverty by 20 million (Cretu 2015).

Romania's RDP 2014-2020 funds actions under all six RD priorities, according to the economic, social and environment dimensions of the sustainable development (Tab. 1).

The total public expenditure of the RDP 2014-2020 is $€ 9.441$ billion. The highest share is allocated to four measures: $26.6 \%$ allocated to Measure 4 - Investments in physical assets, $13.8 \%$ for Measure 13 - Payments to areas facing natural or other specific constraints; $13.8 \%$ is allocated for Measure 7 - Basic services and village renewal in rural areas and $9.5 \%$ allocated to Measure 6 Farm and business development (Tab. 2). 


\section{Priorities of the National Plan for Rural Development 2014-2020 of Romania}

\begin{tabular}{|c|c|}
\hline RD 2014-2020 Priority & Target \\
\hline $\begin{array}{l}\text { Knowledge transfer and } \\
\text { innovation in } \\
\text { agriculture, forestry and } \\
\text { rural areas }\end{array}$ & $\begin{array}{l}\text { - Training for } 184000 \text { persons; } \\
\text { - } 30000 \text { farmers and owners of small processing units will be trained linked } \\
\text { to development of their farm/food businesses (particularly small and } \\
\text { young farmers); } \\
\text { more than } 150000 \text { farmers will be trained on how to better deliver } \\
\text { environmental and climate-related benefits. }\end{array}$ \\
\hline $\begin{array}{l}\text { Food chain organisation, } \\
\text { including processing and } \\
\text { marketing of } \\
\text { agricultural products, } \\
\text { animal welfare and risk } \\
\text { management in } \\
\text { agriculture }\end{array}$ & 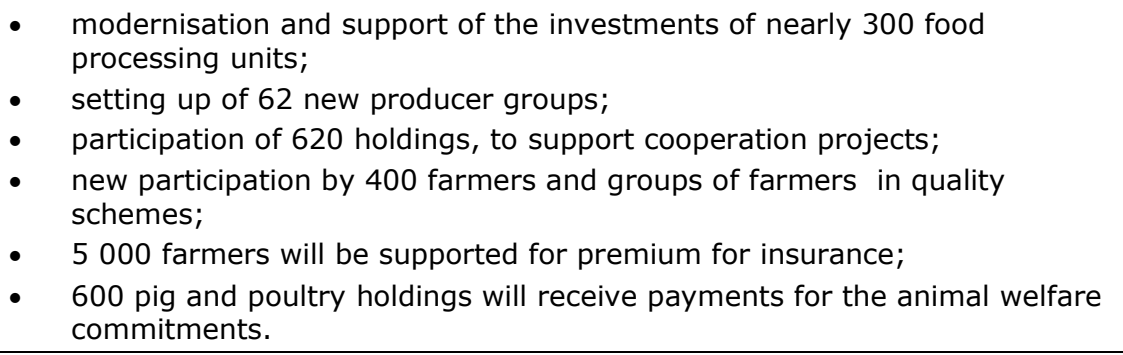 \\
\hline $\begin{array}{l}\text { Restoring, preserving } \\
\text { and enhancing } \\
\text { ecosystems related to } \\
\text { agriculture and forestry }\end{array}$ & $\begin{array}{l}\text { Environmental and climate payments for: } \\
\text { - } \quad \text { Million hectares of agricultural land } \\
\text { - } \quad 800.000 \text { hectares of forest } \\
\text { Payments for organic agricultural practices: } \\
\text { - } \quad 200.000 \text { hectares }\end{array}$ \\
\hline $\begin{array}{l}\text { Resource efficiency and } \\
\text { climate }\end{array}$ & $\begin{array}{l}\text { - } 435 \text { projects for modernisation of existing irrigation infrastructure (for } \\
400.000 \text { hectares of agricultural land); } \\
\text { - } \quad 870 \text { investments targeting the reduction of GHG and NH3 emissions. }\end{array}$ \\
\hline $\begin{array}{l}\text { Social inclusion and } \\
\text { local development in } \\
\text { rural areas }\end{array}$ & $\begin{array}{l}\text { - } \quad 27.000 \text { jobs ( } 2000 \text { will be created under LEADER) } \\
\text { - } 800 \text { projects will be supported to improve small-scale rural infrastructure, } \\
\text { improving living conditions for some } 27 \% \text { of the rural population } \\
\text { - } \quad 400 \text { local cultural patrimony buildings will be restored and preserved }\end{array}$ \\
\hline
\end{tabular}

Source: authors' synthesis -European Commission data

Analysing the current situation, the value of the submitted projects on measure 4 exceeds more than $170 \%$ the financial allocation, the highest exceeding being registered for Measure 4.1a Investments in fruit growing sector and Measure 4.2 - Support for investment in processing/marketing of agricultural products (172\%).

Table 2

Analysis of the projects 2014-2020 (situation on 2019 February $7^{\text {th }}$ )

\begin{tabular}{|l|c|c|c|c|}
\hline \multicolumn{1}{|c|}{ Measure } & $\begin{array}{c}\text { Public } \\
\text { expenditure } \\
\text { (Euro) }\end{array}$ & $\begin{array}{c}\text { Submitted } \\
\text { projects, } \\
\text { value (Euro) }\end{array}$ & $\begin{array}{c}\text { Selected } \\
\text { projects, } \\
\text { value } \\
\text { (Euro) }\end{array}$ & $\begin{array}{c}\text { Approved } \\
\text { projects, } \\
\text { value } \\
\text { (Euro) }\end{array}$ \\
\hline 1.1 Support for vocational training and skills & $\mathbf{5 4 . 1 9 1 . 0 2 2}$ & 30.494 .562 & 14.183 .396 & 3.335 .918 \\
\hline $\begin{array}{l}\text { 1.2 Support for demonstration and } \\
\text { information activities }\end{array}$ & $\mathbf{1 3 . 4 1 4 . 5 0 0}$ & 839.227 & 719.227 & 0 \\
\hline 4.1 Investments in agricultural holdings & $\mathbf{8 4 4 . 6 7 2 . 3 3 8}$ & 2.233 .717 .657 & 865.508 .578 & 649.512 .819 \\
\hline $\begin{array}{l}\text { 4.1 Investments in agricultural holdings ITI } \\
\text { Danube Delta }\end{array}$ & $\mathbf{3 3 . 0 0 0 . 0 0 0}$ & 56.160 .669 & 25.153 .553 & 20.064 .376 \\
\hline 4.1a Investments in fruit growing holdings & $\mathbf{2 8 4 . 3 5 6 . 1 0 9}$ & 401.895 .369 & 244.440 .048 & 178.749 .673 \\
\hline $\begin{array}{l}\text { 4.1a Investments in orchard holdings ITI } \\
\text { Danube Delta }\end{array}$ & $\mathbf{5 . 0 0 0 . 0 0 0}$ & 4.923 .015 & 4.358 .466 & 4.358 .466 \\
\hline $\begin{array}{l}\text { 4.2 Support for investments in the processing } \\
\text { / marketing of agricultural products }\end{array}$ & $\mathbf{3 5 9 . 8 8 3 . 6 9 5}$ & 618.728 .194 & 230.818 .463 & 152.029 .849 \\
\hline $\begin{array}{l}\text { 4.2 Support for investments in the processing } \\
\text { / marketing of agricultural products ITI } \\
\text { Danube Delta }\end{array}$ & $\mathbf{1 0 . 6 0 0 . 0 0 0}$ & 11.489 .693 & 10.959 .866 & 10.380 .115 \\
\hline 4.2 State aid scheme & $\mathbf{1 1 2 . 5 0 0 . 0 0 0}$ & 122.749 .069 & 80.193 .763 & 66.897 .136 \\
\hline 4.2 Minimis Scheme & $\mathbf{1 2 . 5 0 0 . 0 0 0}$ & 805.256 & 614.753 & 614.753 \\
\hline $\begin{array}{l}\text { 4.2a Investments in the processing / } \\
\text { marketing of fruit growing sector products }\end{array}$ & $\mathbf{3 4 . 6 2 9 . 4 3 9}$ & 11.672 .499 & 10.234 .665 & 7.231 .399 \\
\hline
\end{tabular}




\begin{tabular}{|c|c|c|c|c|}
\hline Measure & $\begin{array}{l}\text { Public } \\
\text { expenditure } \\
\text { (Euro) }\end{array}$ & $\begin{array}{l}\text { Submitted } \\
\text { projects, } \\
\text { value (Euro) }\end{array}$ & $\begin{array}{l}\text { Selected } \\
\text { projects, } \\
\text { value } \\
\text { (Euro) } \\
\end{array}$ & $\begin{array}{l}\text { Approved } \\
\text { projects, } \\
\text { value } \\
\text { (Euro) } \\
\end{array}$ \\
\hline $\begin{array}{l}\text { 4.3 Investments for the development, } \\
\text { modernization or adaptation of agricultural } \\
\text { and forestry infrastructure - irrigation }\end{array}$ & 433.978.719 & 226.680 .858 & 189.050 .730 & 180.347 .372 \\
\hline $\begin{array}{l}\text { 4.3 Investments for the development, } \\
\text { modernization or adaptation of agricultural } \\
\text { and forestry infrastructure - irrigation ITI } \\
\text { Danube Delta }\end{array}$ & 7.000 .000 & 6.798 .482 & 6.794 .520 & 6.794 .507 \\
\hline $\begin{array}{l}4.3 \text { Investments for the development, } \\
\text { modernization or adaptation of agricultural } \\
\text { and forestry infrastructure - agricultural } \\
\text { access infrastructure }\end{array}$ & 130.298 .233 & 418.451 .214 & 78.989 .370 & 77.428 .873 \\
\hline 4.3 ITI Danube Delta & 3.000 .000 & 3.452 .793 & 3.347 .047 & 3.347 .047 \\
\hline $\begin{array}{l}4.3 \text { Investments for the development, } \\
\text { modernization and adaptation of the } \\
\text { agricultural and forestry infrastructure - } \\
\text { forestry infrastructure }\end{array}$ & 99.271.119 & 146.722 .415 & 91.277 .869 & 91.032 .475 \\
\hline $\begin{array}{l}\text { 4.3 Investments for the development, } \\
\text { modernization and adaptation of the } \\
\text { agricultural and forestry infrastructure - } \\
\text { forestry infrastructure ITI Danube Delta }\end{array}$ & 1.700 .000 & 1.462 .698 & 1.421 .820 & 1.421 .820 \\
\hline $\begin{array}{l}\text { 6.1 Support for the installation of young } \\
\text { farmers }\end{array}$ & 426.744.132 & 582.350 .000 & 409.630 .000 & 406.460 .000 \\
\hline $\begin{array}{l}\text { 6.1 Support for the installation of young } \\
\text { farmers ITI Danube Delta }\end{array}$ & 10.000 .000 & 9.470 .000 & 8.300 .000 & 8.180 .000 \\
\hline $\begin{array}{l}\text { 6.2 Support for the establishment of non- } \\
\text { agricultural activities in rural areas }\end{array}$ & 106.569 .178 & 345.330 .000 & 111.320 .000 & 108.958 .000 \\
\hline $\begin{array}{l}6.2 \text { Support for the establishment of non- } \\
\text { agricultural activities in rural areas ITI } \\
\text { Danube Delta }\end{array}$ & 5.000 .000 & 15.250 .000 & 4.860 .000 & 4.510 .000 \\
\hline $\begin{array}{l}\text { 6.3 Support for the development of small } \\
\text { farms }\end{array}$ & 246.493.158 & 255.570 .000 & 115.365 .000 & 114.247 .500 \\
\hline $\begin{array}{l}\text { 6.3 Support for the development of small } \\
\text { farms ITI Danube Delta }\end{array}$ & 5.000 .000 & 3.435 .000 & 1.305 .000 & 1.121 .250 \\
\hline $\begin{array}{l}\text { 6.4 Investments in the creation and } \\
\text { development of non-agricultural activities }\end{array}$ & 166.503 .969 & 423.835 .358 & 162.489 .275 & 145.676 .463 \\
\hline $\begin{array}{l}\text { 6.4 Investments in the creation and } \\
\text { development of non-agricultural activities ITI } \\
\text { Danube Delta }\end{array}$ & 10.000 .000 & 17.180 .257 & 9.132 .873 & 6.552 .304 \\
\hline 6.5 Scheme for small farmers & 12.333 .000 & 61.813 & 4.882 & 4.882 \\
\hline $\begin{array}{l}7.2 \text { Investments in the creation and } \\
\text { upgrading of small scale basic infrastructure - } \\
\text { water / waste water infrastructure }\end{array}$ & \multirow{6}{*}{1.109 .058 .285} & 726.335 .354 & 476.597 .571 & 428.247 .490 \\
\hline $\begin{array}{l}7.2 \text { Investments in the creation and } \\
\text { upgrading of small scale basic infrastructure - } \\
\text { water / waste water infrastructure ITI Danube } \\
\text { Delta }\end{array}$ & & 13.204 .837 & 11.729 .437 & 11.729 .437 \\
\hline $\begin{array}{l}7.2 \text { Investments in the creation and } \\
\text { upgrading of small-scale basic infrastructure - } \\
\text { road infrastructure }\end{array}$ & & 1.006 .959 .285 & 510.942 .432 & 494.162 .183 \\
\hline $\begin{array}{l}7.2 \text { Investments in the creation and } \\
\text { upgrading of small-scale basic infrastructure - } \\
\text { road infrastructure of local interest ITI } \\
\text { Danube Delta }\end{array}$ & & 25.754 .682 & 24.700 .601 & 24.700 .601 \\
\hline $\begin{array}{l}7.2 \text { Investing in the creation and upgrading of } \\
\text { small-scale basic infrastructure - educational } \\
\text { and social infrastructure }\end{array}$ & & 168.742 .693 & 121.037 .443 & 116.373 .553 \\
\hline $\begin{array}{l}7.2 \text { Investing in the creation and upgrading } \\
\text { of small-scale basic infrastructure - } \\
\text { educational and social infrastructure ITI } \\
\text { Danube Delta }\end{array}$ & & 2.684 .356 & 1.792 .188 & 1.792 .188 \\
\hline $\begin{array}{l}\text { 7.4 Support for investment in the creation, } \\
\text { improvement or extension of base services for } \\
\text { the rural population, including leisure and } \\
\text { culture, and related infrastructure }\end{array}$ & 13.761 .860 & 0 & 0 & 0 \\
\hline $\begin{array}{l}7.6 \text { Investments associated with the } \\
\text { protection of cultural heritage }\end{array}$ & 188.010 .999 & 304.396 .659 & 211.735.295 & 207.961 .365 \\
\hline
\end{tabular}




\begin{tabular}{|c|c|c|c|c|}
\hline Measure & $\begin{array}{l}\text { Public } \\
\text { expenditure } \\
\text { (Euro) }\end{array}$ & $\begin{array}{l}\text { Submitted } \\
\text { projects, } \\
\text { value (Euro) }\end{array}$ & $\begin{array}{l}\text { Selected } \\
\text { projects, } \\
\text { value } \\
\text { (Euro) }\end{array}$ & $\begin{array}{l}\text { Approved } \\
\text { projects, } \\
\text { value } \\
\text { (Euro) }\end{array}$ \\
\hline $\begin{array}{l}7.6 \text { Investments associated with the } \\
\text { protection of cultural heritage ITI Danube } \\
\text { Delta }\end{array}$ & 9.000 .000 & 4.247 .900 & 4.009 .098 & 4.009 .097 \\
\hline $\begin{array}{l}\text { 8.1 Afforestation and creation of wooded } \\
\text { areas }\end{array}$ & 126.801 .632 & 10.996 .025 & 4.486 .466 & 4.486 .466 \\
\hline 9.1 Establishment of producer groups & 14.736 .313 & 3.674 .879 & 3.670 .419 & 3.370 .418 \\
\hline $\begin{array}{l}\text { 9.1a Establishment of the fruit sector } \\
\text { producer groups }\end{array}$ & 5.300 .811 & 0 & 0 & 0 \\
\hline $\begin{array}{l}\text { 15.1 Payments for commitments in the field } \\
\text { of forestry and climate }\end{array}$ & 70.147.754 & 2.793 .323 & 1.649 .316 & 0 \\
\hline $\begin{array}{l}\text { 16.1 Support for the establishment and } \\
\text { operation of operational groups (GO), for the } \\
\text { development of pilot projects, new products } \\
\text { Stage I- Expression of interest }\end{array}$ & 6.723 .721 & 49.067 .192 & 8.376 .817 & \\
\hline $\begin{array}{l}\text { 16.1a Support for the establishment and } \\
\text { operation of operational groups (GO), for the } \\
\text { development of pilot projects, new products - } \\
\text { fruit sector - Stage I }\end{array}$ & \multirow{2}{*}{5.819 .040} & \multirow{2}{*}{31.125 .190} & \multirow{2}{*}{7.206 .293} & \\
\hline $\begin{array}{l}\text { 16.1a Support for the establishment and } \\
\text { operation of operational groups (GO), for the } \\
\text { development of pilot projects, new products - } \\
\text { fruit sector Stage II }\end{array}$ & & & & \\
\hline $\begin{array}{l}\text { 16.4 Support for horizontal and vertical } \\
\text { cooperation between actors in the supply } \\
\text { chain }\end{array}$ & 10.085 .582 & 11.885 .142 & 5.728 .359 & 4.286 .059 \\
\hline $\begin{array}{l}\text { 16.4a Support for horizontal and vertical } \\
\text { cooperation between actors in the supply } \\
\text { chain -fruit sector }\end{array}$ & 8.728 .560 & 3.437 .443 & 2.122 .246 & 1.808 .062 \\
\hline $\begin{array}{l}\text { 19.1 Preparatory support for the development } \\
\text { of local development strategies }\end{array}$ & 1.990 .183 & 2.435 .307 & 2.379 .233 & 2.224 .725 \\
\hline $\begin{array}{l}19.2 \text { Support for the implementation of } \\
\text { actions within the local development strategy }\end{array}$ & 495.598.466 & 307.847 .362 & 248.210 .323 & 247.563 .169 \\
\hline $\begin{array}{l}\text { 19.3 Preparation and implementation of the } \\
\text { Local Action Group's cooperation activities }\end{array}$ & 16.987 .679 & 173.297 & 80.947 & 15.000 \\
\hline
\end{tabular}

Source: Authors' synthesis based on MADR(2019) -

Romania has also chosen to implement a separate thematic sub-programme (with indicative financial allocation of $€ 320$ million EAFRD funds) aimed to increase the competitiveness and enable restructuring of the fruit growing sector, a sector where Romania has climatic advantages and traditional strengths, but which has suffered from under-investment. Support is given for the setting-up of new orchards, reconversion of the old ones, fruit processing, cooperation projects, and the setting-up of producer groups within the sector (Alecu 2016).

Interventions in the Danube Delta are eligible for funding under five measures; there are two strategic objectives: 1) preservation of unique natural values through environmental management guided by science and by strengthening local communities in their role as proactive protectors of this unique world heritage; and 2) The development of a green, inclusive local economy based on sustainable consumption and protection, resource-efficient, capitalizing on the comparative advantages of the areabenefiting from the support of improved public services (ENRD 2017).

\section{National Plan for Local Development}

NPLD is a multi-annual funding program coordinated by the Ministry of Regional Development and Public Administration from Romania, whose main objective is to support the sustainable development of the administrative-territorial units (MDRAP 2019). 
National Plan for Local Development of Romania

\begin{tabular}{|c|c|c|c|}
\hline Field & $\begin{array}{c}\text { Public expenditure } \\
\text { Stage I - } \\
\text { 2013-2019 (Euro) }\end{array}$ & $\begin{array}{c}\text { Public Expenditure } \\
\text { Stage II- } \\
\text { 2017-2020 (Euro) }\end{array}$ & $\begin{array}{c}\text { Total Payments } \\
\text { 2013-2018 (Euro) }\end{array}$ \\
\hline Water supply & 490.160 .320 & 477.244 .568 & 364.929 .000 \\
\hline Water supply + sewerage & 71.273 .820 & 487.342 .347 & 35.486 .820 \\
\hline Sewerage & 628.756 .452 & 865.043 .894 & 409.365 .290 \\
\hline Roads & 2.207 .640 .433 & 3.130 .386 .742 & 1.762 .914 .738 \\
\hline $\begin{array}{l}\text { Primary schools, } \\
\text { gymnasiums and high } \\
\text { schools }\end{array}$ & 177.475 .784 & 516.071 .492 & 100.332 .031 \\
\hline Kindergarten & 57.591 .381 & 249.568 .475 & 36.621 .783 \\
\hline Medical care units & 2.360 .578 & 229.932 .961 & 11.165 .535 \\
\hline Bridges & 54.595 .981 & 242.697 .785 & 41.123 .214 \\
\hline $\begin{array}{l}\text { Other fields(public } \\
\text { institutions, cultural , } \\
\text { tourism infrastructure) }\end{array}$ & 33.031 .203 & 84.232 .853 & 24.941 .949 \\
\hline Total & C 3,69 billion & c 6,198 billion & C 2,76 billion \\
\hline
\end{tabular}

The achievements of the first stage of the program 2013-2019 were: 5,502 financed investment objectives of which: 3,129 completed targets; total allocation: $€$ 3,69 billion; total allocated 2018: $€ 0.4$ billion (MDRAP 2019). The second phase of the program finances 9,500 investment objectives, of which 2,500 medical care units and kindergartens, 2,000 schools and 5,000 other objectives (from all eligible areas). For these investments, funds amounting to 30 billion lei are committed (Tab. 3).

The comparative analysis of the two NPLD stages emphasizes a raise of $68.75 \%$ of the allocation for local development.

\section{Conclusions}

1) Based on the principle of subsidiarity, Romania selected the rural development measures which fit to national circumstances: negative demographic trend - declining rural population, poor development of non-agricultural activities which generates the rural population's dependence on subsistence agriculture; low level of labor productivity; low level of primary education graduation and high school abandonment of compulsory education compared to urban areas; underdeveloped entrepreneurial culture, characterized by lack of basic managerial knowledge; low income per household; poor quality of tourism infrastructure and rural tourism services; underdeveloped or incomplete basic rural infrastructure (especially in mountain areas) - road, water, sewerage, electricity; limited access to basic social services (health, care of the elderly, kindergartens, etc.); increased share of the rural population at risk of poverty or social exclusion; degradation of traditional settlements with cultural value and historical monuments.

2) The statistical analysis of CMEF baseline indicator data, emphasizes the synergy (including territorial) between national and EU development programs.

3) Analysing the statistical national data, one emphasizes opportunities as: creation of new SMEs with non-agricultural, cultural, creative and cooperative activities in rural areas; further support investment in local agricultural and non-agricultural activities and rural services; development of basic infrastructure and services as a prerequisite for increasing the attractiveness of rural areas; the use of skills and capital assets by persons who have worked on external labor markets 
in the agricultural field; further consolidate core training programs, lifelong learning programs and the development of entrepreneurial skills; the potential of information technology and media to support rural development; further financial support for protecting, preserving local resources (cultural heritage, natural heritage) as a basis for sustainable rural development; creation of brands and participating in quality schemes to generate added value in domestic products; the promoting of local identity; developing packages of financial instruments to support small businesses; strengthen partnerships as a basis for strengthening local strategies that can facilitate innovation, foster cooperation and local economic growth.

\section{Bibliography}

1. Alecu I. N., Stefan P., Cretu R. C., Cutas C. (2016), Proposals Concerning the Promotion Strategy of Food Products in Foreign Markets. Scientific Papers. Series "Management, Economic Engineering in Agriculture and rural development", Vol. 16 ISSUE 1, PRINT ISSN 2284-7995, 31-38.

2. Blewitt, J. (2008), Understanding Sustainable Development, Earthscan Dunstan House, ISBN 978-1-84407-455-6;

3. Cretu,R.F., ,Ciobotar,G.N., Cretu, R.C.( 2015), Survey Regarding the Corporate Governance Implementation in Romania. Scientific Papers. Series „Management, Economic Engineering in Agriculture and rural development", Vol. 15 ISSUE 4, PRINT ISSN 2284-7995, 33-38.

4. Diakosavvas, D. (2006), Coherence of Agricultural and Rural Development Policies, OECD Publishing, ISBN92-64-02388-7;

5. Brandt, H.; Otzen, U.(2007), Poverty Orientated Agricultural and Rural Development, Routledge, Taylor and Francis, ISBN13: 978-0-415-36853-7;

6. Moser, A.; Peter, H.; Fengler, B.; Strohm-Lompcke, R. (2018), Improving the Quality of Life with Rural Development Programmes in Germany (2007-2013): Evidence from the Evaluation, European Countryside, Vol.10 2018 No.2, p.321-339

7. Sheperd, A. (1998) Sustainable Rural Development, Palgrave Publishers Ltd, ISBN 978-0-333-66485-8;

8. Uthes, S.; Li, F.; Kelly, E. (2017), Does EU Rural Expenditure Correspond to Regional Development Needs?, Land Use Policy 60 (2017) 267-280.

9. $\operatorname{AFIR}(2019)$ available at https://www.afir.info/

10. Ministery of Agriculture and Rural Development MADR (2019), available at http://www.madr.ro/pndr2014-2020.html

11. National Program for Rural Development PNDR (2019) available at http://www.pndr.ro/situatia-proiectelordepuse-2014-2020.html

12. Ministery of Regional Development and Public Administration (MDRAP 2019) - National Program for Local Development available at http://www.mdrap.ro/lucrari-publice/pndl. 